\title{
Limited knowledge flow among stakeholders of critically endangered renosterveld in South Africa
}

\author{
$\underline{\text { Stefanie Burghardt }}^{1,2}$, Emmeline N. Topp ${ }^{1,3}$, Karen J. Esler $^{2}$ and Jacqueline Loos $^{1,4}$
}

\begin{abstract}
Despite its status as a biodiversity hotspot, the renosterveld ecosystem within the Greater Cape Floristic Region, South Africa, widely lacks the implementation of measures for biodiversity conservation in the Swartland, even though management plans exist. Though formally protected by law, most renosterveld remnants occur on privately owned agricultural land and therefore depend on private land management. Effective measures, and therefore, effective management of renosterveld for conservation, require various forms of knowledge, including scientific and technical knowledge. Knowledge flows through networks among various stakeholders connected through social relationships and enables individuals to acquire, transmit, and create understanding. We assessed the flow of knowledge and advice through a social network of renosterveld stakeholders. We interviewed 53 individuals, of which 32 were renosterveld private land managers, to determine participants' knowledge sources and network connections. The resulting information and advice networks suggest that land managers are relatively isolated from renosterveld-related knowledge. Of the interviewed land managers, $19 \%$ did not identify any knowledge sources, and $91 \%$ stated they did not receive any advice. Members of academia provided most of the received knowledge (29\%). Seventeen percent of all exchanged knowledge stemmed from governmental organizations, and $5 \%$ from land managers. The findings suggest that renosterveld land managers have limited access to biodiversity knowledge, and there are limited numbers of connections between land managers and external parties (e.g., researchers, conservationists). Thus, the current knowledge sharing structures are insufficient to inform conservation management of critically endangered renosterveld in the Swartland. In this context, bridging organizations and knowledge brokers are crucial components for biodiversity conservation.
\end{abstract}

Key Words: biodiversity conservation; conservation management; habitat fragmentation; knowledge exchange; knowledge network analysis; private land conservation

\section{INTRODUCTION}

The world is experiencing massive biodiversity decline (Balvanera 2019). To focus conservation efforts, priority areas such as global biodiversity hotspots have been identified. Biodiversity hotspots are areas with extraordinary endemism combined with high levels of habitat loss (Myers et al. 2000). When compared to their original extent, the area covered by biodiversity hotspots is estimated to have declined by $85 \%$ (Mittermeier et al. 2011). Landuse change associated with habitat fragmentation and degradation is one of the major drivers linked to this phenomenon (Mooney et al. 1995, Maxwell et al. 2016). Nonetheless, these global biodiversity hotspots contain $>152,000$ plant species, which is $>50 \%$ of all plant species worldwide. Additionally, $69 \%$ of amphibians, $46 \%$ of reptiles, $35 \%$ of birds, and $35 \%$ of mammals occur exclusively in these biodiversity hotspots (Mittermeier et al. 2011).

South Africa's Greater Cape Floristic Region (GCFR) encompasses one of the smallest biodiversity hotspots (Mittermeier et al. 2004), yet it is of global significance (Cowling and Pierce 1999, Myers et al. 2000). Despite its relatively small extent of $87,892 \mathrm{~km}^{2}$ (Rouget et al. 2003), the GCFR is well known for its floristic diversity, hosting approximately 9000 plant species, of which $\sim 70 \%$ are classified as endemic (Goldblatt and Manning 2002). The GCFR contains $\sim 1.9 \%$ of all known plant species worldwide (Myers et al. 2000). Additionally, the region hosts a high diversity of invertebrates (Stuckenberg 1962, Picker and Samways 1996), birds (Stattersfield et al. 1998), mammals (Brooks et al. 2001, Kerley et al. 2003), and other vertebrates such as amphibians and reptiles (Branch 1988, Brooks et al. 2001), many of which are endemic to the GCFR. However, at least $30 \%$ of the GCFR has been extensively transformed because of agricultural expansion, urban development, and the invasion of alien species (Rebelo 1992, Rouget et al. 2003).

Within the GCFR, renosterveld is one of the most transformed vegetation types, yet it contains a high number of threatened plant species (Raimondo et al. 2009; South African National Biodiversity Institute: https://www.sanbi.org/cape/renosterveldremnants-of-the-swartland/). The hallmark of renosterveld lies in the exceptionally high diversity of geophytes (plants with underground storage organs; Cowling 1990). Renosterveld occurs on fertile soil, which is also highly suitable for agriculture. As a result of ploughing for agricultural development, $<10 \%$ of the original extent of renosterveld remains (von Hase et al. 2003). Thus, approximately 18,000 renosterveld remnants (von Hase et al. 2003) exist in a highly fragmented distribution and are mostly found on steep slopes poorly suitable for agriculture. Despite the conservation priority of renosterveld in the GCFR (Rebelo 1997), only $0.6 \%$ of renosterveld is formally protected (Cowling et al. 1999).

Approximately $80 \%$ of South Africa's threatened vegetation types are located on private property (Botha 2001); thus, private land conservation plays an important role in renosterveld conservation (Knight 1999). In other words, renosterveld land managers are integral stakeholders to conserve biodiversity. However, many private renosterveld patches are poorly managed (e.g.,

\footnotetext{
${ }^{1}$ Institute of Ecology, Faculty of Sustainability Science, Leuphana University Lüneburg, Germany, ${ }^{2}$ Department of Conservation Ecology and Entomology, Stellenbosch University, South Africa, ${ }^{3}$ Department of Crop Science, Georg-August University, Germany, ${ }^{4}$ Social-Ecological Systems Institute, Faculty of Sustainability Science, Leuphana University Lüneburg, Germany
} 
overgrazed, invaded by alien species) or remain completely unmanaged (Topp and Loos 2019b). For example, despite fire being an essential ecological driver of renosterveld vegetation, some fragments remain unburned for several decades due to fire suppression by landowners (Cousins et al. 2018). Because of the natural occurrence of renosterveld on largely fertile soils, these shrublands are prone to illegal land transformation or plowing (Rouget et al. 2014). Despite laws and regulations prohibiting the transformation of renosterveld for agriculture, McDowell (1988) claimed that the legislation does not influence a farmers' decision to conserve renosterveld; rather, the willingness to conserve largely depends on the goodwill of land managers (Winter et al. 2007).

Several factors influence an individual's decision-making about whether to engage in conservation (De Snoo et al. 2013, Poppenborg and Koellner 2013). One factor that influences the decision to conserve biodiversity actively is the availability of knowledge (Frick et al. 2004, Ma et al. 2009, Conradie et al. 2013). Land managers possessing good understanding and knowledge of ecosystems are more likely to implement conservation practices (Knight et al. 2010). During any decision-making process, decision makers often draw on different forms of knowledge such as local-ecological, experiential, scientific, and technical knowledge (Gorddard et al. 2016, Colloff et al. 2017). In particular, for ecosystem management to be effective, decision makers require a combination of these different knowledge forms (Reed et al. 2011, Bieling and Plieninger 2017). Local-ecological knowledge can enable decision makers (i.e., land managers) to understand ecosystem dynamics and the interactions with biodiversity (Olsson and Folke 2001). Experiential knowledge allows land managers to learn from experience and to develop the ability to reconsider existing mind-sets (Fazey et al. 2006). Additionally, effective conservation management requires access to new scientific information combined with a level of technical knowledge to evaluate which management techniques can be beneficial for the ecosystem (Lauber et al. 2011, Cvitanovic et al. 2015).

Land managers' decisions are not made in isolation (Rickenbach and Reed 2002, Bergmann and Bliss 2004), but are at least partly influenced by knowledge that is shared via social networks (Burt 1992, Rogers 1995, De Villiers et al. 2014). The social networks of individuals from the same stakeholder cluster thus influence their decisions to take part in conservation initiatives (Kittredge et al. 2013, Groce et al. 2019). Moreover, land managers frequently consult experts for information when it comes to decision-making (West et al. 1988) because it remains challenging for a single person to possess the in-depth knowledge needed to manage ecosystems for biodiversity conservation (Brown 2003, Olsson et al. 2004, Carlsson and Berkes 2005). Protected areas as well as private land conservation areas can be considered socialecological systems that interact continuously with social, economic, and political contexts (Cumming et al. 2015). Such systems also simultaneously evolve with each other across temporal and spatial scales (Folke 2007), requiring the capacity to react and reorganize in times of change (Folke et al. 2005). Acknowledging ecosystems as complex adaptive systems with social and ecological components represents one approach to dealing with uncertainty and abrupt change (Folke et al. 2005). Multistakeholder participation has somewhat proven to enhance information exchange and improve plans to manage socialecological systems (Colfer 2005). Accessing and exchanging knowledge with various stakeholders across different governance levels (vertical links) requires social networks that mobilize ecosystem management information and advice (Olsson et al. 2006). Social interactions among, for example, family members, friends, or neighbors (horizontal links) can facilitate the distribution of information, which, in turn, causes changes in attitudes, decisions, and behavior (Christakis and Fowler 2007, 2008, Borgatti and Halgin 2011).

Here, we assess the nature of social networks and knowledge exchange among renosterveld stakeholders. Our aim was to determine from whom farmers obtain knowledge about how to manage this critically endangered ecosystem, and with whom they consult for renosterveld related decision-making. Social network analysis is a powerful diagnostic tool to identify stakeholders in ecosystem management and biodiversity conservation (Bodin and Crona 2009, Bodin and Prell 2011) and their relational patterns (Reed et al. 2009, Vance-Borland and Holley 2011). Studying social networks can identify the flow of knowledge, information, or ideas (Valente and Davis 1999, Borgatti and Halgin 2011) and thereby spot gaps in knowledge exchange between stakeholders and land managers, which can help to improve collaborative conservation action (Vance-Borland and Holley 2011, Mills et al. 2014) in highly threatened renosterveld.

We present a knowledge network analysis by applying the social network analysis method to investigate the flow of information and advice among stakeholders in renosterveld conservation in the Swartland, South Africa. We addressed the following research questions: (1) Who are the stakeholders of renosterveld conservation and what are their network characteristics in terms of information and advice exchange? (2) Do sources of information differ from sources of advice? (3) Which stakeholders are important for the dissemination of knowledge? (4) How are land managers integrated in the overall knowledge networks? (5) What are the most common fields of knowledge shared in the knowledge networks? By conducting this knowledge network analysis, we sought to gain an understanding of the knowledge exchange to identify opportunities for more effective management of renosterveld on private lands.

\section{METHODS}

\section{Study area}

We focused on renosterveld conservation in and near the Swartland Municipality, Western Cape Province, South Africa (Fig. 1). The Swartland covers approximately $3700 \mathrm{~km}^{2}$, with the Bergrivier Municipality and Saldanha Bay Municipality to the north, the Drakenstein Municipality to the east, and the City of Cape Town to the south. The region is characterized by a typically Mediterranean-type climate, with wet, cold winters and dry, hot summers (Cowling et al. 1997). Approximately $80 \%$ of the annual precipitation of 400 to $750 \mathrm{~mm}$ falls between May and October (Halpern and Meadows 2013). The landscape is characterized by agricultural monocultures of wheat, canola, grapes, and pastures for livestock (Midgley et al. 2005, Metelerkamp 2011, Department of Agriculture, Forestry and Fisheries 2018). Because of its fertile soils and close proximity to Cape Town, the Swartland has been extensively transformed to agriculture since 
the beginning of colonialism in the 17 th century, but especially due to rapid urbanization in the 20th century (Newton and Knight 2005). Renosterveld fragments remain mostly on privately owned farmland in areas that are difficult to cultivate, such as steep and rocky slopes. As a result of recent agricultural expansion, the Swartland's natural renosterveld vegetation has declined from $11.23 \%$ in 1960 to $2.5 \%$ in 2010 (Halpern and Meadows 2013). Most renosterveld fragments are privately owned, cover $<0.5$ ha (von Hase et al. 2003), and remain, to a large extent, on hilltops or steep slopes that are poorly suitable for agricultural purposes (McDowell and Moll 1992).

Fig. 1. Map showing the locations of the Swartland municipality, the remaining extent of renosterveld, and the participating land managers with renosterveld remnants on their land (renosterveld properties).

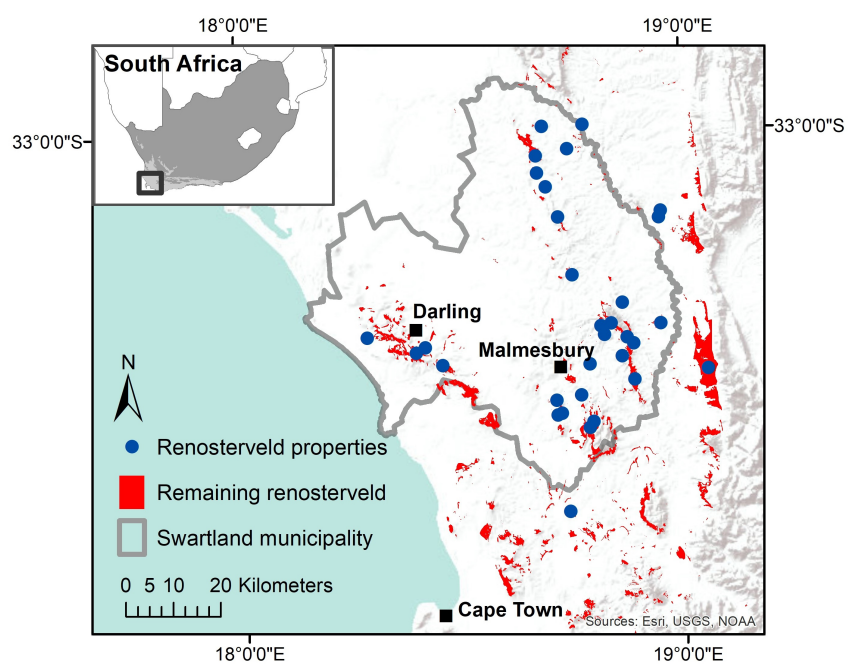

\section{Data collection}

To identify renosterveld conservation stakeholders in the Swartland, we applied snowball sampling. This sampling method uses an initial group of participants to nominate other stakeholders relevant to the study (Prell 2011). We initially contacted land managers who owned renosterveld and were selected using a stratified random approach in a previous study of butterfly diversity in the region (Topp and Loos 2019b). We interviewed these individuals and asked them to identify other stakeholders of renosterveld conservation. We then conducted follow-up interviews with the stakeholders that were mentioned and repeated the process until a network mapping saturation point was reached and no new stakeholders were mentioned (Leventon et al. 2016). We first interviewed land managers (first step), their primary sources (second step) as well as subsequent sources (third and fourth steps). After we acquired an interviewee's consent and explained the purpose of the study, we conducted a semistructured interview following a questions guide (Appendix 1). We asked about individuals or organizations with whom the interviewee had communicated regarding renosterveld conservation. In five follow-up questions, we asked for knowledge sources and details about their relationships to the source (e.g., frequency of communication). To examine whether individuals obtained information and advice from the same knowledge sources or whether a portfolio of knowledge sources with different expertise existed, we differentiated between two distinct knowledge networks: (1) sources of information and (2) sources of advice (Table 1). Sources of information represent comprehensive firsthand information from media such as books or magazines, as well as collaborations with individuals and the exchange of detailed and precise facts about renosterveld. Sources of advice refers to connections with other renosterveld stakeholders and the exchange of practical recommendations (Glückler et al. 2017), on-the-ground activities, or broader management activities, whereas information refers to passing on knowledge without any specific action to be followed based on that knowledge.

Table 1. List of interview questions and their corresponding knowledge network.

\begin{tabular}{ll}
\hline \hline Interview question & Network \\
\hline What are your primary sources of information about & Information \\
renosterveld conservation? & \\
$\begin{array}{l}\text { From whom have you gotten the most accurate } \\
\text { information regarding renosterveld conservation in the }\end{array}$ & Information \\
$\begin{array}{l}\text { last five years? } \\
\begin{array}{l}\text { From whom have you gotten advice regarding renosterveld } \\
\text { conservation in the last five years? }\end{array}\end{array}$ \\
$\begin{array}{l}\text { From whom have you gotten new or innovative ideas } \\
\text { regarding renosterveld conservation in the last five years? }\end{array}$ & Advice \\
$\begin{array}{l}\text { Who have you contacted for implementing any change } \\
\text { regarding renosterveld conservation in the last five years? }\end{array}$ & Advice \\
\hline
\end{tabular}

\section{Network mapping and analysis}

All steps during the mapping and analysis process were performed using Gephi 0.9.2, a free and open-source network analysis and visualization software (Bastian et al. 2009). Prior to this step, identified stakeholders were assigned to one of eight stakeholder clusters, according to their primary affiliation: academia (A), citizen scientist $(\mathrm{C})$, conservation initiative $(\mathrm{CI})$, governmental organization (GO), land manager (LM), media (M), nongovernmental organization (NGO), and other (O). The last category included, among others, independent consultants and members of the local fire department. For confidentiality reasons, pseudonyms were used for each stakeholder that refer to the stakeholder's affiliated cluster.

\section{Network mapping}

To provide an overview of the various responses, the two knowledge networks were respectively mapped from two different perspectives: (1) single stakeholder and (2) cluster. The singlestakeholder perspective allows the identification of all stakeholders, including their relations, whereas the cluster-based perspective enables the reader to distinguish quickly which clusters are most important for the supply of knowledge. The single-stakeholder perspective portrays all named renosterveld conservation stakeholders and their relationships. It thus provides an overview of the entire knowledge network. Here, individuals or organizations are represented as nodes and may be sources and recipients of knowledge, simultaneously. The directed links (called edges) between any two nodes illustrate knowledge flow, i.e., from source to recipient (Borgatti et al. 2018). We used the 
isometric layout in Gephi (http://www.relationalcapitalvalue. com/gephiplugins.html) because it allows splitting networks into different layers. We found that the single-stakeholder perspective shows three distinct vertical layers: land managers at the bottom, their knowledge sources in the center (primary knowledge sources), and knowledge sources mentioned in follow-up interviews (secondary knowledge sources) at the top. Because our research contemplates the entire knowledge network and evaluates land managers' knowledge sources, this approach rapidly distinguishes between land managers and other knowledge sources. However, central stakeholders or key players are not necessarily displayed in the center of the network, and the proximity between any two nodes is not scaled. In contrast, the cluster-based perspective primarily illustrates the knowledge flow between land manager and the eight stakeholder clusters and shows which clusters provide knowledge and to what extent these clusters play a role as a conduit for the exchange of knowledge for land managers.

\section{Network analysis}

Several network metrics describe, summarize, or analyze a knowledge network at multiple levels emphasizing distinct aspects (Hansen et al. 2020). We used four different sets of network metrics to address multiple aims (Table 2). First, to provide an overview of the whole knowledge network and to assess structural properties, we calculated network cohesion metrics, including size, number of edges, average degree, network diameter, density, and average path length, for both the information and the advice networks (Hanneman and Riddle 2014). The size is the total number of nodes in a network, the number of edges represents the knowledge exchange between nodes, and average degree is the resulting average number of links per node in a network. The diameter represents the longest path (in number of edges) between two nodes in the network. The smaller the diameter, the more compact the network. Network density is the proportion of all possible links existing in a network, and the average path length shows the average number of steps between any two nodes (Prell 2011, Vance-Borland and Holley 2011, Hanneman and Riddle 2014).

Table 2. Overview of the analysis levels and aims, and the corresponding network metrics used.

\begin{tabular}{lll}
\hline \hline Level & Analysis aim & Network metric \\
\hline 1 & $\begin{array}{l}\text { Description of whole } \\
\text { network }\end{array}$ & $\begin{array}{l}\text { Size, number of edges, average } \\
\text { degree, network diameter, density, } \\
\text { average path length }\end{array}$ \\
2 & $\begin{array}{l}\text { Node-centrality for: } \\
\text { Key knowledge source } \\
\text { identification }\end{array}$ & $\begin{array}{l}\text { In-degree centrality, eigenvector } \\
\text { centrality }\end{array}$ \\
2.2 & $\begin{array}{l}\text { Key knowledge source } \\
\text { identification }\end{array}$ & In-degree centrality \\
2.3 & $\begin{array}{l}\text { Key cluster identification } \\
\text { Level of farmer integration }\end{array}$ & $\begin{array}{l}\text { In-degree centrality } \\
\text { Out-degree centrality }\end{array}$ \\
\hline
\end{tabular}

Second, to pinpoint key knowledge sources having an important role in knowledge dissemination, two network metrics were applied: in-degree centrality and eigenvector centrality. Whereas in-degree centrality represents the number of edges directed to the node (Freeman 1979), eigenvector centrality does not consider all links as equal and is therefore a measure of a node's influence within a network (Newman 2008). These node-centrality metrics were calculated to identify: (1) key knowledge sources within the entire knowledge network, (2) key knowledge sources among land managers only, and (3) key clusters providing most of the knowledge for land managers. For (1), in-degree centrality and eigenvector centrality were calculated, whereas for (2) and (3), only in-degree centrality was calculated. The centrality of a stakeholder and, hence, the effectivity of knowledge diffusion, is based on the knowledge source's position in the network. Several node centrality metrics are available, each emphasizing different aspects of a node within a network (Mbaru and Barnes 2017). Degree centrality reflects the level of activity or involvement of a node in a network (Wasserman and Faust 1994, Prell 2011). We used in-degree centrality because it reflects which knowledge source provides most of the knowledge to other stakeholders. Moreover, we used in-degree centrality to investigate knowledge exchange horizontally (i.e., among land managers) and vertically (i.e., with governmental institutions) because these links were identified as important in natural resource management (Calhoun et al. 2014, Roux et al. 2016). Nevertheless, degree centrality only considers the total number of links and does not account for linked nodes and how influential they may be (Hansen et al. 2020). Thus, degree centrality is a quantitative rather than qualitative indicator. To include the qualitative perspective, we used eigenvector centrality, which represents how well a stakeholder is connected to other stakeholders and how well-connected their connections are (Bonacich 1972). Thus, high eigenvector centrality indicates a stakeholder's tendency to have a wide reach in the network, which allows widespread knowledge dissemination across the network (Mbaru and Barnes 2017).

Third, to assess the extent of land managers' involvement in the entire knowledge network, we calculated out-degree centrality. This metric shows the level of integration of a stakeholder or a cluster within a network (Prell 2011) and quantifies how many knowledge sources each cluster relies on. Each knowledge source cluster was determined separately, and they were subsequently compared. In contrast to in-degree and eigenvector centrality, out-degree centrality was calculated for interviewed individuals only. Additionally, we tested whether land managers involved in conservation initiatives or flower tourism activities showed higher numbers of information or advice sources.

Finally, we also investigated which field of information or advice was exchanged among renosterveld stakeholders. Thus, while asking about knowledge sources of renosterveld information and advice, we also enquired about the content of information and advice shared between the source and the recipient. Responses were clustered and compared among the following six renosterveld information and advice topics: conservation and restoration, ecology, fire management, land management, scientific research, and other fields of expertise.

\section{RESULTS}

We conducted 53 interviews in total. We categorized the interviewees into the following knowledge source clusters: citizen scientists $(N=2)$, academia $(N=3)$, other $(N=4)$, NGOs $(N=$ $4)$, GOs $(N=8)$, and land managers $(N=32)$. The interviews were conducted in a mix of English and Afrikaans and transcribed into English in full with the help of a translator. 
Fig. 2. Network diagram of the information network for renosterveld conservation. The color of a node represents the knowledge source cluster the individual is associated with; $\mathrm{GO}=$ governmental organization, $\mathrm{NGO}=$ nongovernmental organization. The size of the node indicates the in-degree centrality (number of links entering the node). Labels are shown for stakeholders with an in-degree $\geq 2$. Arrows point to the information source that was named. Six landowners did not have any information source. A09 had the highest in-degree centrality ( $N$ =22), followed by GO08 $(N=15)$.

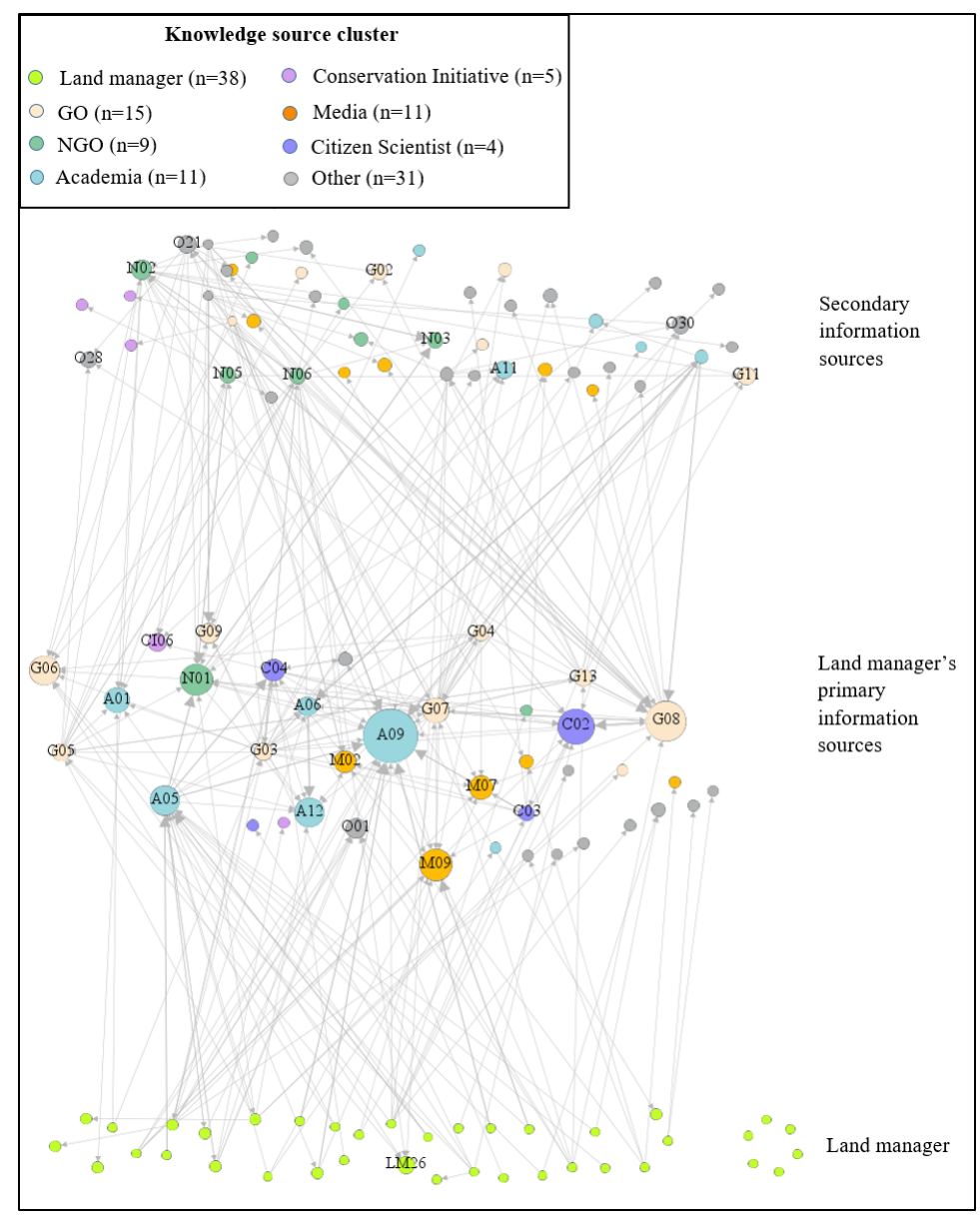

\section{Renosterveld conservation stakeholders and their knowledge networks}

Overall, we reached saturation with 134 identified renosterveld conservation stakeholders in the Swartland region. In general, the two knowledge networks, (1) information and (2) advice, differed considerably in size, number of edges, average degree, density, diameter, and average path length. The information network consisted of 124 stakeholders with 288 links, corresponding to an average of 2.32 links per stakeholder (Table 3, Fig. 2). The advice network was considerably smaller, comprising 67 stakeholders with 55 links, corresponding to an average degree of 0.82 (Fig. 3 ). The density in both knowledge networks showed $<2 \%$ of all possible links evident. The greatest number of steps (network diameter) between any two nodes was eight in the information network and three in the advice network, indicating that the information network is the least compact network. This result corresponded with the average path length, which was 3.04 in the information network and 1.40 in the advice network.

Table 3. Summary of network metrics for the information and advice networks.

\begin{tabular}{lcccccc}
\hline \hline Network & Size & $\begin{array}{c}\text { Number of } \\
\text { edges }\end{array}$ & $\begin{array}{c}\text { Average } \\
\text { degree }\end{array}$ & Density & $\begin{array}{c}\text { Network } \\
\text { diameter }\end{array}$ & $\begin{array}{c}\text { Average } \\
\text { path length }\end{array}$ \\
\hline $\begin{array}{l}\text { Informa- } \\
\text { tion }\end{array}$ & 124 & 288 & 2.32 & 0.019 & 8 & 3.04 \\
Advice & 67 & 55 & 0.82 & 0.012 & 3 & 1.40 \\
\hline
\end{tabular}

\section{Key knowledge sources and clusters}

To identify stakeholders responsible for knowledge transmission and dissemination in Swartland renosterveld, in-degree and 
Fig. 3. Network diagram of the advice network for renosterveld conservation. The color of a node represents the knowledge source cluster the individual is associated with; $\mathrm{GO}=$ governmental organization, $\mathrm{NGO}=$ nongovernmental organization. The size of the node indicates the in-degree centrality (number of links entering the node). Labels are shown for stakeholders with an in-degree $\geq 2$. Arrows point to the advice source that was named. Twenty-nine landowners did not have any advice source. A09 had the highest in-degree centrality ( $N$ $=13)$, followed by $\operatorname{NGO01}(N=9)$.

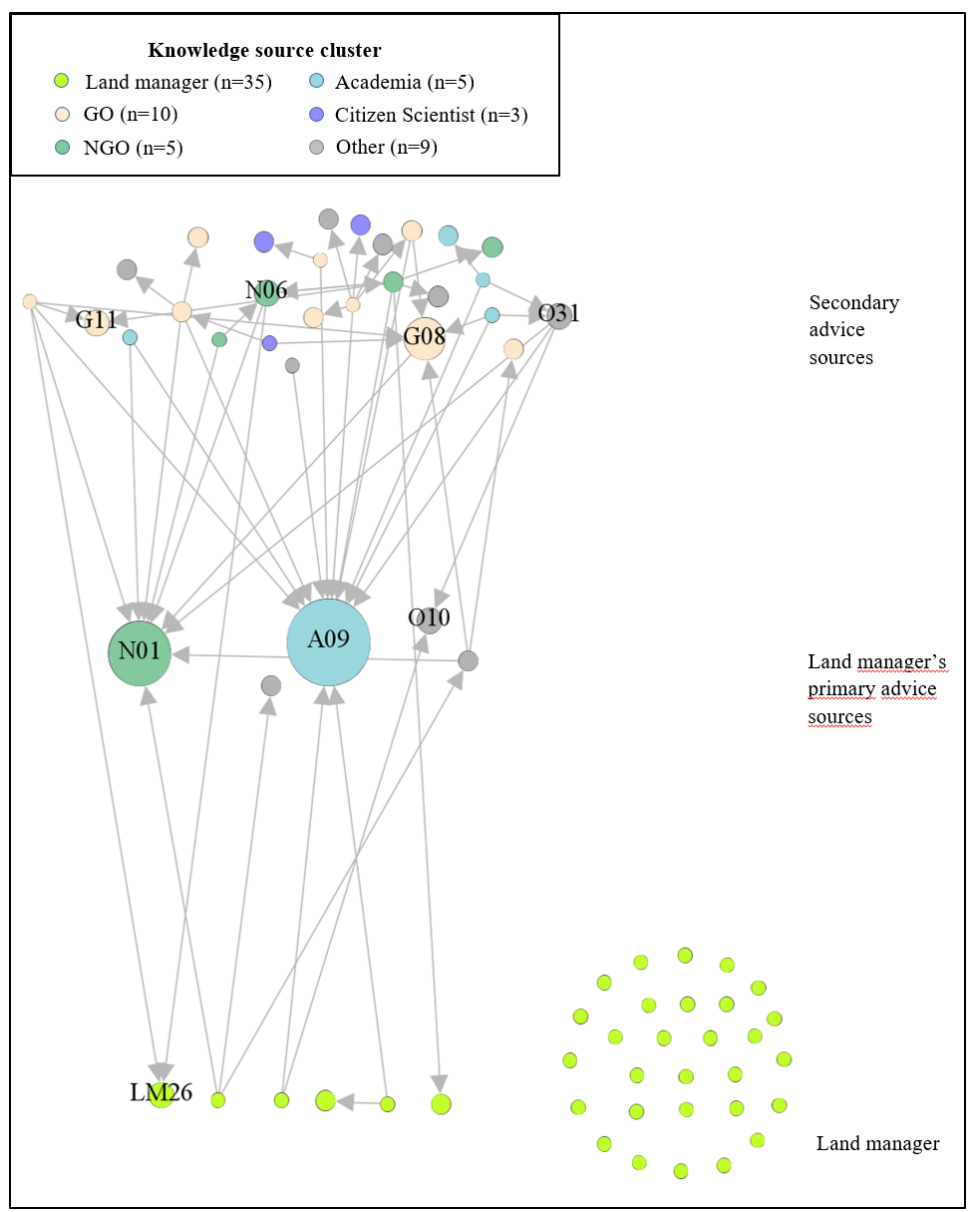

eigenvector centrality were calculated. The top five knowledge sources were assessed (Table 4). Individual A09, a previous PhD student of Stellenbosch University, named by 22 interviewees $(N$ $=22)$, and GO08 $(N=15)$ of CapeNature were the mostmentioned information sources. Based on eigenvector centrality, A09 (1.0) and NGO01 (0.67), a representative of the Overberg Renosterveld Conservation Trust, an NGO based in the Overberg dedicated to renosterveld conservation, were identified as key individuals for information dissemination. Similar results were found in the advice network, with A09 $(N=13)$ and NGO01 $(N$ $=9$ ) important regarding in-degree centrality. In terms of eigenvector centrality, NGO01 (1.0) and A09 (0.71) were important for providing advice.

The most frequently mentioned source of information by landowners was A05 $(N=10)$, who had previously conducted research on renosterveld in the area, followed by $\mathrm{A} 09(N=8)$. Considering those land managers who received advice, A09 was named by two land managers and NGO01 by one individual.

Additionally, we investigated which and to what extent clusters provide information and advice to land managers (Fig. 4). Overall, land managers received knowledge mainly from academia (29\%). Horizontal links among land managers accounted for $5 \%(N=4)$ of all knowledge received by land managers. On a vertical axis, seven land managers received knowledge from GOs, accounting for $17 \%(N=15)$ of all knowledge exchanged with land managers. Furthermore, the cluster mostly mentioned as sources of information included academia (29\%), GOs $(19 \%)$, and other $(19 \%)$, including independent consultants. Advice mainly derived from other (43\%) and academia $(29 \%)$. 
Table 4. Central knowledge sources in the two knowledge networks, ranked by two different centrality measures. Uppercase letters in parentheses and knowledge-source pseudonyms indicate the stakeholders' associated cluster: $\mathrm{A}=$ academia, $\mathrm{C}=$ citizen scientist, $\mathrm{GO}=$ governmental organization, $\mathrm{M}=$ media, $\mathrm{NGO}=$ nongovernmental organization, $\mathrm{O}=$ other.

\begin{tabular}{|c|c|c|c|c|c|}
\hline \multirow[b]{2}{*}{ Network } & \multirow[b]{2}{*}{ Rank } & \multicolumn{2}{|c|}{ In-degree centrality } & \multicolumn{2}{|c|}{ Eigenvector centrality } \\
\hline & & $\begin{array}{c}\text { Knowledge } \\
\text { source }\end{array}$ & Measure & Knowledge source & $\begin{array}{c}\text { Meas- } \\
\text { ure }\end{array}$ \\
\hline \multirow[t]{5}{*}{ Information } & 1 & A09 (A) & 22 & A09 (A) & 1.00 \\
\hline & 2 & $\mathrm{GO} 08(\mathrm{G})$ & 15 & $\mathrm{NGO} 01(\mathrm{~N})$ & 0.67 \\
\hline & 3 & CREW (C) & 13 & $\begin{array}{l}\text { Scientific literature } \\
\text { (A) }\end{array}$ & 0.66 \\
\hline & 4 & Magazines (M) & 11 & GO08 $(\mathrm{G})$ & 0.66 \\
\hline & 5 & NGO01 (N) & 11 & CREW (C) & 0.64 \\
\hline \multirow[t]{5}{*}{ Advice } & 1 & A09 (A) & 13 & NGO01 (N) & 1.00 \\
\hline & 2 & NGO01 (N) & 9 & A09 (A) & 0.71 \\
\hline & 3 & $\mathrm{GO} 08(\mathrm{G})$ & 5 & $\begin{array}{l}\text { Land managers } \\
\text { (LM) }\end{array}$ & 0.40 \\
\hline & 4 & $\begin{array}{c}\text { Fire department } \\
(\mathrm{O})\end{array}$ & 2 & GO11 (G) & 0.39 \\
\hline & 5 & $\mathrm{GO} 11(\mathrm{G})$ & 2 & NGO06 (N) & 0.39 \\
\hline
\end{tabular}

Fig. 4. Flow charts of the proportional knowledge provision in the different clusters containing land managers. (A) Overall knowledge sharing, (B) information sharing, and (C) advice sharing. Percentages in parentheses indicate the share of knowledge from each source cluster. Lines illustrate knowledge exchange, line thickness indicates the number of times a knowledge source cluster was mentioned, arrows point to the cluster that was named, and numbers beneath give the total number of links.

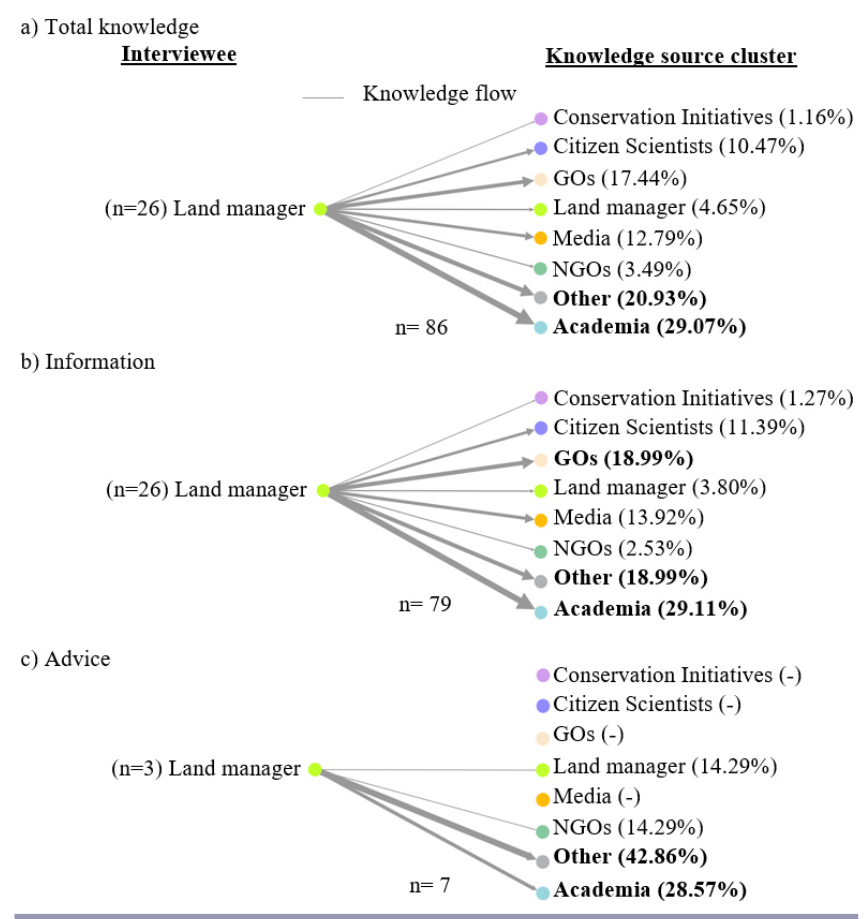

\section{Integration of land managers in knowledge networks}

To assess the level of integration of land managers in the two knowledge networks, we calculated out-degree centrality for each cluster (Table 5). No stakeholders from the clusters "conservation initiatives" and "media" were interviewed, hence the out-degree of 0 . Stakeholders in the information network showed an average out-degree of 5.76. However, comparing among clusters, land managers had the smallest average out-degree of 2.47. Overall, six farmers $(19 \%)$ reported that they did not receive any information or advice on renosterveld management. Members from GOs showed the highest out-degree of 11.50 links per stakeholder. When it comes to receiving advice, the average outdegree was 1.04, where land managers had the smallest out-degree of 0.22 , and members of NGOs the highest of 2.75. Only three land managers received advice from seven knowledge sources on renosterveld managing practices; hence, 29 farmers (91\%) do not frequently obtain practical recommendations regarding renosterveld (Fig. 3).

Table 5. Comparison of out-degree (number of outgoing links) among the knowledge source clusters and between the two knowledge networks. Out-degree refers to the total number of outgoing links per knowledge source cluster, the out-degree average reflects the outgoing links on average per member of the knowledge source cluster.

\begin{tabular}{lcccccc}
\hline \hline & \multicolumn{2}{c}{$\begin{array}{c}\text { Information } \\
\text { network }\end{array}$} & & \multicolumn{2}{c}{ Advice network } \\
\cline { 2 - 3 } Knowledge cluster & $\begin{array}{c}\text { Out- } \\
\text { degree }\end{array}$ & $\begin{array}{c}\varnothing \text { out- } \\
\text { degree }\end{array}$ & & $\begin{array}{c}\text { Out- } \\
\text { degree }\end{array}$ & $\begin{array}{c}\text { Ø out- } \\
\text { degree }\end{array}$ \\
\hline Academia & 27 & 9.00 & & 8 & 2.67 \\
Citizen scientist & 14 & 7.00 & & 2 & 1.00 \\
Conservation initiatives & 0 & 0.00 & & 0 & 0.00 \\
Governmental organizations & 92 & 11.50 & & 20 & 2.50 \\
Land managers & 79 & 2.47 & & 7 & 0.22 \\
Media & 0 & 0.00 & & 0 & 0.00 \\
Nongovernmental & 44 & 11.00 & & 11 & 2.75 \\
organizations & 32 & 8.00 & & 7 & 1.75 \\
Other & 288 & 5.76 & 55 & 1.04 \\
Total & & & &
\end{tabular}

Additionally, we tested whether land managers involved in conservation initiatives or flower tourism activities showed higher numbers of information or advice sources (Fig. 5). Because three land managers showed seven sources of advice in total, we show this comparison for information sources only. Land managers engaged in any conservation activities $(N=7)$ showed significantly more links (average 6.43) to other renosterveld knowledge sources compared to land managers not involved in any conservation initiatives or flower tourism $(N=25$, average 1.36).

Furthermore, we assessed the content of the knowledge received by land managers, including both information and advice. Most of the information received by land managers was ecological information such as the abundance of species (68\%). Seven percent of all information received contained fire management information. However, $22.5 \%$ of the total advice communicated with land managers was related to renosterveld ecology, for example, the needs of a certain species or how to broadcast indigenous grass seeds. Recommendations for land management practices accounted for $30 \%$ of all advice given. 
Fig. 5. Boxplots of the number of information sources for renosterveld land managers in the Swartland region involved in conservation or flower tourism activities and land managers not involved in conservation activities.

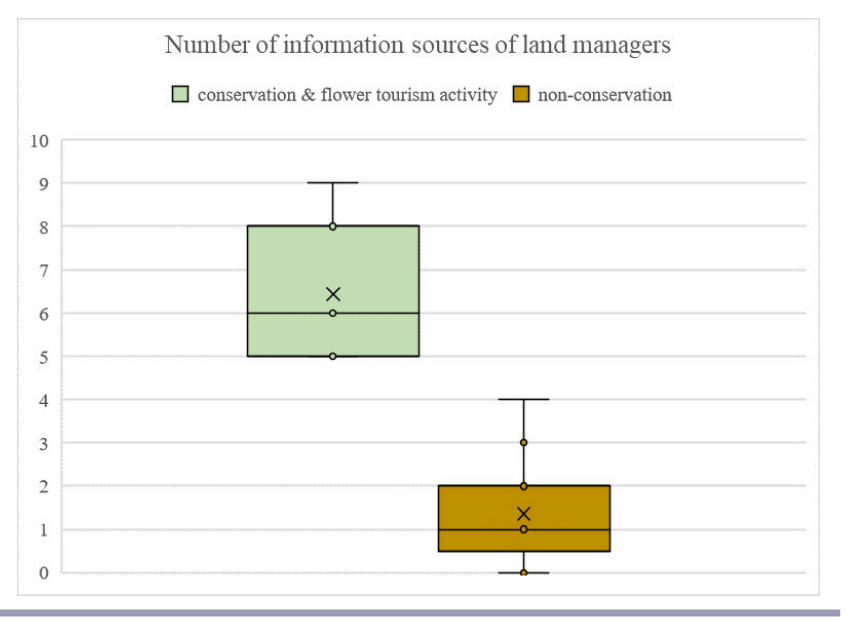

\section{DISCUSSION}

We examined knowledge flow and limitations regarding critically endangered renosterveld on private land in the Swartland region. We identified clear differences between information and advice networks and in the degree of integration of land managers into the overall knowledge network. We first discuss the finding that renosterveld land managers are isolated from many information sources. We then discuss the lack of horizontal and vertical knowledge exchange before pointing out options for governance improvements through enhanced collaborations.

\section{Land managers' isolation in renosterveld management}

The results showed that $19 \%$ of land managers have no knowledge links to the rest of the stakeholders in the knowledge networks. In comparison to other clusters, land managers were identified as the group with the least number of information sources (2.47) and advice sources (0.22). However, land managers involved in any kind of conservation activity showed a higher average for information sources (6.43) compared to land managers not involved in conservation (1.36). Overreliance on one or two stakeholders may result in a less resilient network overall. This factor is particularly important for information networks, where a higher density of stakeholders in the network increases the capacity of the network to withstand the removal of links, meaning that information can continue to flow through the network (Janssen et al. 2006). If a network member is lost or the composition of stakeholders in the network changes, a lowdensity network may have little buffering capacity and may struggle to maintain its identity (Bodin et al. 2006, Janssen et al. 2006). This situation is dependent on the remaining stakeholders being able to fulfill the same function or role, i.e., sharing information; thus, the composition of stakeholders also has implications for network resilience. In networks where scientists and practitioners work together, their traditional roles may become more flexible, allowing for co-production of knowledge, which can flow in multiple directions (Vogel et al. 2007).
Although we found that land managers reported obtaining knowledge about renosterveld, many renosterveld remnants in private ownership are unmanaged or lack management for biodiversity protection (Topp and Loos 2019b), suggesting that this knowledge does not translate to effect management practices. The principal type of information passed through the information network was about renosterveld ecology, including information on renosterveld-dependent species. Other studies have found that providing some information about species increased land managers' desire to obtain more information about endangered species and their needs, increasing their awareness (e.g., Olive and McCune 2017). Ultimately, this process could contribute to farmers' awareness to avoid habitat destruction (Clark and McLeman 2012). Despite renosterveld requiring active management, land managers reported limited communication of information about such management strategies, for instance, fire management or alien vegetation clearing guidelines (Topp and Loos 2019a). Although fire is an important driver for ecological processes in renosterveld vegetation (Cousins et al. 2018), only $7 \%$ of all exchanged renosterveld information pertained to fire. Thus, the limited knowledge obtained by renosterveld land managers may result in a lack of understanding of renosterveld dynamics.

\section{Lack of cross-level knowledge exchange}

Our mapped knowledge networks reveal a lack of horizontal and vertical linkages with and among renosterveld land managers. We identified little vertical knowledge exchange between land managers and subordinate governmental institutions. In South Africa, the South African National Biodiversity Institute (SANBI) oversees the facilitation of vertical and horizontal collaborations across environmental and agricultural sectors (Roux et al. 2016). This oversight includes, for instance, the topdown implementation of the global Aichi biodiversity targets, which is facilitated through SANBI and its provincial agencies. In the Western Cape Province, CapeNature is the responsible entity for biodiversity conservation (Goodness and Anderson 2014). CapeNature's Conservation Stewardship Programme aims to establish partnerships with private land managers, offering a variety of options tailored to the need of the land managers to optimize conservation management on privately owned land (https://www.capenature.co.za/protected-areas-and-stewardship). Although CapeNature has implemented 127,550 ha of private lands into stewardship programs since 2002 (Turner 2012), our study suggests that linkages to renosterveld land managers in the Swartland region are still limited. Of the 32 farmers interviewed, 7 exchanged knowledge with members of GOs, and 5 of those are involved to some extent in renosterveld conservation (i.e., ecotourism, nature reserves, etc.), which suggests that GOs are not very important sources of knowledge for land managers.

While the reach of government agencies and implementation of management agreements may be limited, in part due to capacity constraints coupled with extensive negotiation processes (von Hase et al. 2010, Selinske et al. 2015), we found examples of successful collaborations among GOs and land managers in the region. However, additional challenges remain for scaling up of these agreements for landscape-wide conservation. For example, some extension services that were previously offered by the government, such as assistance with alien vegetation, are no longer in place (Liebenberg 2015). Furthermore, land managers 
voiced their concerns over GOs' involvement in managing their land. Similar findings of mistrust toward governmental agencies were found in a study with owners of private land conservation areas elsewhere in South Africa (Cousins et al. 2010, Pasquini et al. 2010, Conradie et al. 2013) and in Australia (Raymond et al. 2015). Historical mistrust of many South Africans toward the government may be amplified by the recent land reform developments, resulting in growing fear of land loss (Institute for Poverty, Land and Agrarian Studies 2016, Spierenburg 2020), which is a challenge for vertical collaborations in conservation networks.

Horizontal collaborations have been found to be highly important for natural resource management (e.g., Olsson et al. 2007, Calhoun et al. 2014, Roux et al. 2016). We therefore asked land managers whether they obtained information or advice on renosterveld management from their farming neighbors or other members of the farming community. We found only four links among land managers. Surprisingly, at least three farmers mentioned that they did not at any time communicate with the neighboring farms about farming practices. This result has implications for renosterveld management because some renosterveld remnants border several farms and are owned by multiple land managers (Topp and Loos 2019b). Successful conservation management practices in these patches would therefore require collective decision-making and action. A study conducted with protected areas in the Western and Eastern Cape of South Africa found that informal relationships and spatial proximity seem to affect protected area management stronger than organizational governance (Maciejewski and Cumming 2015). In fact, some land managers pointed out that there was mutual support with water delivery and fire suppression in case of a fire outbreak. In times of crisis, neighboring farms support each other. As De Villiers et al. (2014) affirmed, land managers in the Karoo region of the Western Cape felt that they could seek advice or help in times of crisis from almost any neighbor. Their result indicates a potential starting point to increase the information flow in the network for informed decision-making.

\section{Polycentric governance for renosterveld conservation}

The isolation of farmers in knowledge networks and the lack of renosterveld conservation may be attributed to several factors, including the lack of governance capacity to improve collaborations and negative attitudes of farmers toward renosterveld (McDowell et al. 1989, Winter et al. 2005, 2007, von Hase et al. 2010). Scholars such as Cash and Moser (2000) and Cumming et al. (2006) have stressed the importance of recognizing environmental management as complex and multiscale. Therefore, alternative governance solutions are required to address the multiple scales of management.

In this context, the concept of polycentric governance (Folke et al. 2007, Biggs et al. 2012, Guerrero et al. 2015) may present a promising approach to address these challenges in the Swartland. Polycentric governance describes a system with various interacting units or authorities, linked across horizontal and vertical dimensions, governing within a specific geographic area or policy arena (Biggs et al. 2012). Given the finding that land managers are relatively isolated from GOs, higher level governance institutions may need to collaborate more closely with farmers in the Swartland to facilitate and promote renosterveld conservation. However, because some land managers find it difficult to trust GOs, there may be reluctance in accepting a topdown conservation approach. Nevertheless, the inclusion of GOs and trust in their managerial ability are important preconditions for successful collaboration in conservation (Wondolleck and Yaffee 2000, Armitage et al. 2009, Kozar et al. 2014), particularly in seriously threatened ecosystems such as renosterveld.

\section{Importance of bridging organizations, individual human agency,} and knowledge brokers in renosterveld conservation

Alongside polycentric governance, bridging organizations, which link stakeholders across jurisdictions, can improve existing collaborations across governance levels (Cash et al. 2006, Folke et al. 2007). Bridging organizations in renosterveld conservation may facilitate vertical interactions and knowledge flow between local governments and farmers. As an example, the NGO Overberg Renosterveld Conservation Trust acts as an intermediary by facilitating the exchange and co-production of knowledge. Because managing ecosystems is information intensive (Ma et al. 2009) and requires a blend of different forms of knowledge (Bieling and Plieninger 2017), co-production of knowledge represents a promising approach (Nel et al. 2016). Through long-term studies and monitoring, scientific and nonscientific knowledge can be combined collaboratively to design effective conservation strategies (trial and error). The Overberg Renosterveld Conservation Trust, in tandem with land managers, designs distinct renosterveld management plans. This strategy of knowledge co-production assists land managers in receiving an improved understanding of renosterveld dynamics. By signing onto an easement program, farmers receive technical and financial assistance to conserve the renosterveld remnant. The Overberg Renosterveld Conservation Trust is one of the first organizations in South Africa working with easement strategies (Wright 2019) and has conserved 1345 ha of critically endangered renosterveld (Overberg Renosterveld Conservation Trust 2018). These strategies have been shown as promising for conservation in other Mediterranean-type biodiversity hotspots (Cox and Underwood 2011).

Individual human agency and leadership capabilities are crucial for the success of bridging organizations (Cash et al. 2006). Individual human agency describes the capacity of individuals to facilitate transformation toward a more sustainable system. With regard to conservation, these individuals are also referred to as conservation champions (Gilmour et al. 1999, Napier et al. 2005), change agents (Crawford et al. 2006), stewards (Olsson and Folke 2001), or brokers (Bebbington 1997). While possessing a key role in social networks, change agents facilitate a common vision among stakeholders, influence beliefs, mobilize knowledge flow (Westley et al. 2013), and shape perceptions of credibility and legitimacy of knowledge (Cash et al. 2003). For example, the staff of the Kristianstads Vattenrike Biosphere Reserve in Sweden played a crucial role in the transformation toward a new governance regime by linking people, sharing and generating knowledge, and developing a common vision (Olsson et al. 2007). In our study, A09 could be considered a conservation champion; however, we argue that more individuals like A09 are needed to increase the network's resilience.

We found that university members played a significant role in the transmission of renosterveld knowledge through the network. 
However, the role of conservation champions, brokers, or stewards is not limited to members of academia. Land managers can play a key role in conservation efforts, given that they are sole owners of renosterveld land (Selinske et al. 2015, Maciejewski et al. 2016). Considering knowledge as a prerequisite for decisionmaking (Frick et al. 2004, Gorddard et al. 2016), farmers in the renosterveld are currently unlikely to be agents in renosterveld management because of relatively low levels of knowledge and awareness of renosterveld ecology and biological value (Winter et al. 2007). Hence, there is genuine need for knowledge brokers to act as facilitators of knowledge exchange among renosterveld stakeholders and toward renosterveld land managers. Knowledge brokers translate complex matters into understandable language, which enables the knowledge recipient to act (Gerrish et al. 2011, Verbeke et al. 2011). In the Swartland, knowledge brokers could therefore forward information and advice from different experts in the knowledge networks to renosterveld land managers and provide feedback responses from the farmers. Thus, applicable renosterveld management techniques and strategies could be designed collaboratively. Because brokers act as channels for knowledge exchange, different forms of knowledge required for renosterveld management can be shared (e.g., information on legislation, ecological processes such as fire, invasive species removal, and the needs of specific renosterveld species), and new or modified knowledge can be created collectively (e.g., renosterveld species present in landowners' remnants, site-specific best practices; Meyer 2010, Fazey et al. 2013). The exchange of knowledge and management strategies between farmers offers possibilities for collective learning and improvement in renosterveld management (Maciejewski and Cumming 2015). Through this approach, farmers can be empowered to be stewards themselves and facilitate bottom-up approaches in renosterveld conservation.

We emphasize the need to establish a blend of top-down and bottom-up approaches to fulfill all required roles in renosterveld conservation. While top-down approaches such as CapeNature's stewardship program is important in the conservation of private lands, complementary bridging organizations and individual change agents are also required to foster collective action. To achieve collective action, personal contact with land managers is crucial (McDowell et al. 1989), paired with commitment to maintenance support and guidance (Winter et al. 2007). Winter et al.'s (2007) study indicated that land managers were open to conservation incentives and to receiving assistance from local conservation authorities. This information is consistent with the impressions we gained during the interviews; however, most of the farmers indicated that they did not know who to contact in this regard. Therefore, we suggest that initial contact should derive from the conservation agency.

\section{Recommendations for future research}

More research is required to understand how to promote collaboration, how to motivate land managers to become more integrated into renosterveld knowledge networks, and how to enhance government incentives such as CapeNature's Conservation Stewardship Programme. Our study illustrates a snapshot of social interactions among the various stakeholders in the knowledge networks and does not monitor the shifting nature of relationships. One shortcoming in conservation science is the lack of assessment of conservation outcomes (Ferraro and
Pattanayak 2006, Bottrill and Pressey 2012), which limits the understanding of the effectiveness of network interventions to improve knowledge exchange for conservation (KochoSchellenberg and Berkes 2015) and network evolution (Sandström and Lundmark 2016). Hence, studies with longitudinal data collection at multiple time points are needed (Groce et al. 2019). Using our findings as a starting point, further research could contribute toward a better understanding of how the knowledge and collaboration networks evolve over time. Additionally, evaluating the flow of agricultural knowledge among the same stakeholders would provide a valuable opportunity for comparison with the conservation knowledge network. Such work may allow the identification of links in the network that could be leveraged to prioritize conservation.

\section{CONCLUSION}

We assessed knowledge exchange in terms of information and advice among stakeholders for conservation of a critically endangered habitat in the Cape Floristic Region. We identified a relatively low exchange of advice compared to information sharing. In both networks, academic stakeholders were found to be a central knowledge source regarding in-degree and eigenvector centrality. However, knowledge exchange about conservation management was scarce among stakeholders. Particularly, we found limited evidence of horizontal links (i.e., among land managers themselves). Additionally, vertical knowledge exchange with GOs was limited. To increase the resilience of local networks, achieving a blend of top-town and bottom-up communication strategies seems desirable. Bridging organizations and knowledge brokers can play a vital role in mobilizing different types of knowledge and linking various stakeholders from different bodies across governance levels. Collaborations among various stakeholders and increased engagement with land managers is required for privately owned ecosystem remnants. In this context, face-to-face contact seems crucial to establish good relationships with land managers and to design management practices collaboratively which, when coupled with different forms of knowledge, can assist in meeting renosterveld conservation targets. Our findings support the design of a robust and flexible knowledge network to improve conservation governance in renosterveld, and the results may similarly transfer to other biodiversity hotspots.

Responses to this article can be read online at: https://www.ecologyandsociety.org/issues/responses. php/12083

\section{Acknowledgments:}

This work is dedicated to Stephen Cousins, a previous PhD student at Stellenbosch University. We thank all participants of this study, as well as Chima Onwunta, Dr. Martina Treurnicht, and Friederike Sieve. The German Research Foundation [DFG, LO 2323/1-1] funded the research project. $S B$ acknowledges a grant from the German Academic Exchange Service. The Robert-Bosch Foundation supports JL through a Junior Professorship for Research into Sustainable Use of Natural Resources. 


\section{Data Availability:}

The datalcode that support the findings of this study are available on request from the corresponding author.

\section{LITERATURE CITED}

Armitage, D. R., R. Plummer, F. Berkes, R. I. Arthur, A. T. Charles, I. J. Davidson-Hunt, A. P. Diduck, N. C. Doubleday, D. S. Johnson, M. Marschke, P. McConney, E. W. Pinkerton, and E. K. Wollenberg. 2009. Adaptive co-management for socialecological complexity. Frontiers in Ecology and the Environment 7(2):95-102. https://doi.org/10.1890/070089

Balvanera, P. 2019. Societal burdens of nature loss. Science 366 (6462):184-185. https://doi.org/10.1126/science.aaz1433

Bastian, M., S. Heymann, and M. Jacomy. 2009. Gephi: an open source software for exploring and manipulating networks. Pages 361-362 in Proceedings of the international AAAI conference on web and social media. PKP Publishing Services, Vancouver, Canada. [online] URL: https://ojs.aaai.org/index.php/ICWSM/ article/view/13937

Bebbington, A. 1997. Social capital and rural intensification: local organizations and islands of sustainability in the rural Andes. Geographical Journal 163(2):189-197. https://doi.org/10.2307/3060182

Bergmann, S. A., and J. C. Bliss. 2004. Foundations of crossboundary cooperation: resource management at the publicprivate interface. Society and Natural Resources 17(5):377-393. https://doi.org/10.1080/08941920490430142

Bieling, C., and T. Plieninger. 2017. Leveraging landscape stewardship: principles and ways forward. Pages 370-382 in C. Bieling and T. Plieninger, editors. The science and practice of landscape stewardship. Cambridge University Press, Cambridge, UK. https://doi.org/10.1017/9781316499016.037

Biggs, R., M. Schlüter, D. Biggs, E. L. Bohensky, S. BurnSilver, G. Cundill, V. Dakos, T. M. Daw, L. S. Evans, K. Kotschy, A. M. Leitch, C. Meek, A. Quinlan, C. Raudsepp-Hearne, M. D. Robards, M. L. Schoon, L. Schultz, and P. C. West. 2012. Toward principles for enhancing the resilience of ecosystem services. Annual Review of Environment and Resources 37:421-448. https://doi.org/10.1146/annurev-environ-051211-123836

Bodin, Ö., and B. I. Crona. 2009. The role of social networks in natural resource governance: What relational patterns make a difference? Global Environmental Change 19(3):366-374. https:// doi.org/10.1016/j.gloenvcha.2009.05.002

Bodin, Ö., B. Crona, and H. Ernstson. 2006. Social networks in natural resource management: What is there to learn from a structural perspective? Ecology and Society 11(2):r2. https://doi. org/10.5751/ES-01808-1102r02

Bodin, Ö., and C. Prell. 2011. Social networks and natural resource management: uncovering the social fabric of environmental governance. Cambridge University Press, Cambridge, UK. https://doi.org/10.1017/CBO9780511894985

Bonacich, P. 1972. Technique for analyzing overlapping memberships. Sociological Methodology 4:176-185. https://doi. org/10.2307/270732
Borgatti, S. P., M. G. Everett, and J. C. Johnson. 2018. Analyzing social networks. Second edition. Sage, Thousand Oaks, California, USA.

Borgatti, S. P., and D. S. Halgin. 2011. On network theory. Organization Science 22(5):1168-1181. https://doi.org/10.1287/ orsc. 1100.0641

Botha, M. 2001. Conservation options for farmers and private landholders. Summary report. Cape Conservation Unit, Botanical Society of South Africa, Cape Town, South Africa.

Bottrill, M. C., and R. L. Pressey. 2012. The effectiveness and evaluation of conservation planning. Conservation Letters 5 (6):407-420. https://doi.org/10.1111/j.1755-263X.2012.00268.x

Branch, W. R., editor. 1988. South African red data book: reptiles and amphibians. Foundation for Research Development, Pretoria, South Africa.

Brooks, T., A. Balmford, N. Burgess, J. Fjeldså, L. A. Hansen, J. Moore, C. Rahbek, and P. Williams. 2001. Toward a blueprint for conservation in Africa: a new database on the distribution of vertebrate species in a tropical continent allows new insights into priorities for conservation across Africa. BioScience 51 (8):613-624. https://doi.org/10.1641/0006-3568(2001)051[0613: TABFCI]2.0.CO;2

Brown, K. 2003. Integrating conservation and development: a case of institutional misfit. Frontiers in Ecology and the Environment 1(9):479-487. https://doi.org/10.1890/1540-9295 (2003)001[0479:ICADAC]2.0.CO:2

Burt, R. S. 1992. Structural holes: the social structure of competition. Harvard University Press, Cambridge, Massachusetts, USA.

Calhoun, A. J. K., J. S. Jansujwicz, K. P. Bell, and M. L. Hunter Jr. 2014. Improving management of small natural features on private lands by negotiating the science-policy boundary for Maine vernal pools. Proceedings of the National Academy of Sciences 111(30):11002-11006. https://doi.org/10.1073/pnas.1323606111

Carlsson, L., and F. Berkes. 2005. Co-management: concepts and methodological implications. Journal of Environmental Management 75(1):65-76. https://doi.org/10.1016/j.jenvman.2004.11.008

Cash, D. W., W. N. Adger, F. Berkes, P. Garden, L. Lebel, P. Olsson, L. Pritchard, and O. Young. 2006. Scale and cross-scale dynamics: governance and information in a multilevel world. Ecology and Society 11(2):8. https://doi.org/10.5751/ES-01759-110208

Cash, D. W., W. C. Clark, F. Alcock, N. M. Dickson, N. Eckley, D. H. Guston, J. Jäger, and R. B. Mitchell. 2003. Knowledge systems for sustainable development. Proceedings of the National Academy of Sciences 100(14):8086-8091. https://doi.org/10.1073/ pnas. 1231332100

Cash, D. W., and S. C. Moser. 2000. Linking global and local scales: designing dynamic assessment and management processes. Global Environmental Change 10(2):109-120. https://doi. org/10.1016/S0959-3780(00)00017-0

Christakis, N. A., and J. H. Fowler. 2007. The spread of obesity in a large social network over 32 years. New England Journal of Medicine 357(4):370-379. https://doi.org/10.1056/NEJMsa066082 
Christakis, N. A., and J. H. Fowler. 2008. The collective dynamics of smoking in a large social network. New England Journal of Medicine 358(21):2249-2258. https://doi.org/10.1056/NEJMsa0706154

Clark, K., and R. A. McLeman. 2012. Maple sugar bush management and forest biodiversity conservation in eastern Ontario, Canada. Small-scale Forestry 11:263-284. https://doi. org/10.1007/s11842-011-9183-X

Colfer, C. J. P. 2005. The complex forest: communities, uncertainty, and adaptive collaborative management. Resources for the Future Press, Washington, D.C., USA. https://doi. org/10.4324/9781936331727

Colloff, M. J., B. Martín-López, S. Lavorel, B. Locatelli, R. Gorddard, P.-Y. Longaretti, G. Walters, L. van Kerkhoff, C. Wyborn, A. Coreau, R. M. Wise, M. Dunlop, P. Degeorges, H. Grantham, I. C. Overton, R. D. Williams, M. D. Doherty, T. Capon, T. Sanderson, and H. T. Murphy. 2017. An integrative research framework for enabling transformative adaptation. Environmental Science and Policy 68:87-96. https://doi. org/10.1016/j.envsci.2016.11.007

Conradie, B., M. Treurnicht, K. Esler, and M. Gaertner. 2013. Conservation begins after breakfast: the relative importance of opportunity cost and identity in shaping private landholder participation in conservation. Biological Conservation 158:334-341. https://doi.org/10.1016/j.biocon.2012.08.028

Cousins, J. A., J. P. Sadler, and J. Evans. 2010. The challenge of regulating private wildlife ranches for conservation in South Africa. Ecology and Society 15(2):28. https://doi.org/10.5751/ $\underline{\text { ES-03349-150228 }}$

Cousins, S. R., E. T. F. Witkowski, and K. J. Esler. 2018. Influence of fire on critically endangered Swartland Shale Renosterveld in the Cape Floristic Region. Applied Vegetation Science 21 (1):144-155. https://doi.org/10.1111/avsc.12348

Cowling, R. M. 1990. Diversity components in a species-rich area of the Cape Floristic Region. Journal of Vegetation Science 1 (5):699-710. [online] URL: https://www.jstor.org/stable/3235578

Cowling, R. M., and S. M. Pierce. 1999. Cape Floristic Province. Pages 218-227 in R. A. Mittermeier, C. Goettsch Mittermeier, N. Myers, and G. P. Robles, editors. Hotspots: Earth's biologically richest and most endangered terrestrial ecoregions. CEMEX, Mexico City, Mexico, and Conservation International, Washington, D.C., USA.

Cowling, R. M., R. L. Pressey, A. T. Lombard, P. G. Desmet, and A. G. Ellis. 1999. From representation to persistence: requirements for a sustainable system of conservation areas in the species-rich Mediterranean-climate desert of southern Africa. Diversity and Distributions 5(1-2):51-71. https://doi.org/10.1046/ j.1472-4642.1999.00038.x

Cowling, R. M., D. M. Richardson, and P. J. Mustart. 1997. Fynbos. Pages 99-130 in R. M. Cowling, D. M. Richardson, and S. M. Pierce, editors. Vegetation of southern Africa. Cambridge University Press, Cambridge, UK.

Cox, R. L., and E. C. Underwood. 2011. The importance of conserving biodiversity outside of protected areas in Mediterranean ecosystems. Plos One 6(1):e14508. https://doi. org/10.1371/journal.pone.0014508
Crawford, B., M. Kasmidi, F. Korompis, and R. B. Pollnac. 2006. Factors influencing progress in establishing community-based marine protected areas in Indonesia. Coastal Management 34 (1):39-64. https://doi.org/10.1080/08920750500379300

Cumming, G. S., C. R. Allen, N. C. Ban, D. Biggs, H. C. Biggs, D. H. M. Cumming, A. De Vos, G. Epstein, M. Etienne, K. Maciejewski, R. Mathevet, C. Moore, M. Nenadovic, and M. Schoon. 2015. Understanding protected area resilience: a multiscale, social-ecological approach. Ecological Applications 25 (2):299-319. https://doi.org/10.1890/13-2113.1

Cumming, G. S., D. H. M. Cumming, and C. L. Redman. 2006. Scale mismatches in social-ecological systems: causes, consequences, and solutions. Ecology and Society 11(1):14. https://doi.org/10.5751/ES-01569-110114

Cvitanovic, C., A. J. Hobday, L. van Kerkhoff, S. K. Wilson, K. Dobbs, and N. A. Marshall. 2015. Improving knowledge exchange among scientists and decision-makers to facilitate the adaptive governance of marine resources: a review of knowledge and research needs. Ocean and Coastal Management 112:25-35. https://doi.org/10.1016/j.ocecoaman.2015.05.002

de Snoo, G. R., I. Herzon, H. Staats, R. J. F. Burton, S. Schindler, J. van Dijk, A. M. Lokhorst, J. M. Bullock, M. Lobley, T. Wrbka, G. Schwarz, and C. J. M. Musters. 2013. Toward effective nature conservation on farmland: making farmers matter. Conservation Letters 6(1):66-72. https://doi.org/10.1111/j.1755-263X.2012.00296. $\underline{x}$

de Villiers, A. C., K. J. Esler, and A. T. Knight. 2014. Social processes promoting the adaptive capacity of rangeland managers to achieve resilience in the Karoo, South Africa. Journal of Environmental Management 146:276-283. https://doi.org/10.1016/ j.jenvman.2014.08.005

Department of Agriculture, Forestry and Fisheries. 2018. Trends in the agricultural sector 2017. Department of Agriculture, Forestry and Fisheries, Pretoria, South Africa. [online] URL: https://www.dalrrd.gov.za/Portals/0/Statistics $\% 20$ and $\% 20$ Economic $\%$ 20Analysis/

Statistical $\% 20$ Information/Trends $\% 20 \mathrm{in} \% 20$ the $\% 20$ Agricultural $\%$ 20Sector $\% 202017 . p d f$

Fazey, I., A. C. Evely, M. S. Reed, L. C. Stringer, J. Kruijsen, P. C. L. White, A. Newsham, L. Jin, M. Cortazzi, J. Phillipson, K. Blackstock, N. Entwistle, W. Sheate, F. Armstrong, C. Blackmore, J. Fazey, J. Ingram, J. Gregson, P. Lowe, S. Morton, and C. Trevitt. 2013. Knowledge exchange: a review and research agenda for environmental management. Environmental Conservation 40 (1):19-36. https://doi.org/10.1017/S037689291200029X

Fazey, I., J. A. Fazey, J. G. Salisbury, D. B. Lindenmayer, and S. Dovers. 2006. The nature and role of experiential knowledge for environmental conservation. Environmental Conservation 33 (1):1-10. https://doi.org/10.1017/S037689290600275X

Ferraro, P. J., and S. K. Pattanayak. 2006. Money for nothing? A call for empirical evaluation of biodiversity conservation investments. Plos Biology 4(4):e105. https://doi.org/10.1371/ journal.pbio.0040105

Folke, C. 2007. Social-ecological systems and adaptive governance of the commons. Ecological Research 22(1):14-15. https://doi.org/10.1007/s11284-006-0074-0 
Folke, C., T. Hahn, P. Olsson, and J. Norberg. 2005. Adaptive governance of social-ecological systems. Annual Review of Environment and Resources 30:441-473. https://doi.org/10.1146/ annurev.energy.30.050504.144511

Folke, C., L. Pritchard, F. Berkes, J. Colding, and U. Svedin. 2007. The problem of fit between ecosystems and institutions: ten years later. Ecology and Society 12(1):30. https://doi.org/10.5751/ ES-02064-120130

Freeman, L. C. 1979. Centrality in social networks conceptual clarification. Social Networks 1(3):215-239. https://doi. org/10.1016/0378-8733(78)90021-7

Frick, J., F. G. Kaiser, and M. Wilson. 2004. Environmental knowledge and conservation behavior: exploring prevalence and structure in a representative sample. Personality and Individual Differences 37(8):1597-1613. https://doi.org/10.1016/j.paid.2004.02.015

Gerrish, K., A. McDonnell, M. Nolan, L. Guillaume, M. Kirshbaum, and A. Tod. 2011. The role of advanced practice nurses in knowledge brokering as a means of promoting evidencebased practice among clinical nurses. Journal of Advanced Nursing 67(9):2004-2014. https://doi.org/10.1111/j.1365-2648.2011.05642. $\underline{\mathrm{x}}$

Gilmour, A., G. Walkerden, and J. Scandol. 1999. Adaptive management of the water cycle on the urban fringe: three Australian case studies. Conservation Ecology 3(1):11. https:// doi.org/10.5751/ES-00107-030111

Glückler, J., E. Lazega, and I. Hammer, editors. 2017. Knowledge and networks. Springer, Berlin, Germany. https://doi. org/10.1007/978-3-319-45023-0

Goldblatt, P., and J. C. Manning. 2002. Plant diversity of the Cape Region of southern Africa. Annals of the Missouri Botanical Garden 89(2):281-302. https://doi.org/10.2307/3298566

Goodness, J., and P. M. L. Anderson. 2014. Local assessment of Cape Town: navigating the management complexities of urbanization, biodiversity, and ecosystem services in the Cape Floristic Region. Pages 461-484 in T. Elmqvist, M. Fragkias, J. Goodness, B. Güneralp, P. J. Marcotullio, R. I. McDonald, S. Parnell, M. Schewenius, M. Sendstad, K. C. Seto, and C. Wilkinson, editors. Urbanization, biodiversity and ecosystem services: challenges and opportunities: a global assessment. Springer Dordrecht, The Netherlands. https://doi. org/10.1007/978-94-007-7088-1 24

Gorddard, R., M. J. Colloff, R. M. Wise, D. Ware, and M. Dunlop. 2016. Values, rules and knowledge: adaptation as change in the decision context. Environmental Science and Policy 57:60-69. https://doi.org/10.1016/j.envsci.2015.12.004

Groce, J. E., M. A. Farrelly, B. S. Jorgensen, and C. N. Cook. 2019. Using social-network research to improve outcomes in natural resource management. Conservation Biology 33(1):53-65. https://doi.org/10.1111/cobi.13127

Guerrero, A. M., R. R. J. Mcallister, and K. A. Wilson. 2015. Achieving cross-scale collaboration for large scale conservation initiatives. Conservation Letters 8(2):107-117. https://doi. org/10.1111/conl.12112
Halpern, A. B. W., and M. E. Meadows. 2013. Fifty years of land use change in the Swartland, Western Cape, South Africa: characteristics, causes and consequences. South African Geographical Journal 95(1):38-49. https://doi.org/10.1080/0373$\underline{6245.2013 .806101}$

Hanneman, R. A., and M. Riddle. 2014. Concepts and measures for basic network analysis. Pages 340-369 in J. Scott and P. J. Carrington, editors. The Sage handbook of social network analysis. Sage, Thousand Oaks, California, USA. https://doi. org/10.4135/9781446294413.n24

Hansen, D. L., B. Shneiderman, M. A. Smith, and I. Himelboim. 2020. Social network analysis: measuring, mapping, and modeling collections of connections. Pages 31-51 in D. L. Hansen, B. Shneiderman, M. A. Smith, and I. Himelboim, editors. Analyzing social media networks with NodeXL. Second edition. Morgan Kaufmann, Burlington, Massachusetts, USA. https:// doi.org/10.1016/B978-0-12-817756-3.00003-0

Institute for Poverty, Land and Agrarian Studies. 2016. Diagnostic report on land reform in South Africa. Commissioned report for high level panel on the assessment of key legislation and the acceleration of fundamental change, an initiative of the parliament of South Africa. Institute for Poverty, Land and Agrarian Studies, University of the Western Cape, Bellville, South Africa. [online] URL: https://www.parliament.gov.za/storage/ app/media/Pages/2017/october/High Level Panel/

Commissioned_Report_land/Diagnostic_Report_on_Land_Reform in South Africa.pdf

Janssen, M. A., Ö. Bodin, J. M. Anderies, T. Elmqvist, H. Ernstson, R. R. J. McAllister, P. Olsson, and P. Ryan. 2006. Toward a network perspective of the study of resilience in socialecological systems. Ecology and Society 11(1):15. https://doi. org/10.5751/ES-01462-110115

Kerley, G. I. H., R. L. Pressey, R. M. Cowling, A. F. Boshoff, and R. Sims-Castley. 2003. Options for the conservation of large and medium-sized mammals in the Cape Floristic Region hotspot, South Africa. Biological Conservation 112(1-2):169-190. https:// doi.org/10.1016/S0006-3207(02)00426-3

Kittredge, D. B., M. G. Rickenbach, T. G. Knoot, E. Snellings, and A. Erazo. 2013. How personal connections shape decisions about private forest use. Northern Journal of Applied Forestry 30(2):67-74. https://doi.org/10.5849/njaf.11-004

Knight, A. T., R. M. Cowling, M. Difford, and B. M. Campbell. 2010. Mapping human and social dimensions of conservation opportunity for the scheduling of conservation action on private land. Conservation Biology 24(5):1348-1358. https://doi. org/10.1111/j.1523-1739.2010.01494.X

Knight, R. L. 1999. Private lands: the neglected geography. Conservation Biology 13(2):223-224. https://doi.org/10.1046/ j.1523-1739.1999.013002223.x

Kocho-Schellenberg, J.-E., and F. Berkes. 2015. Tracking the development of co-management: using network analysis in a case from the Canadian Arctic. Polar Record 51(4):422-431. https:// doi.org/10.1017/S0032247414000436

Kozar, R., L. E. Buck, E. G. Barrow, T. C. H. Sunderland, D. E. Catacutan, C. Planicka, A. K. Hart, and L. Willemen. 2014. 
Toward viable landscape governance systems: What works? EcoAgriculture Partners, on behalf of the Landscapes for People, Food, and Nature Initiative, Washington, D.C., USA. [online] URL: https://www.cifor.org/knowledge/publication/4814/

Lauber, T. B., R. C. Stedman, D. J. Decker, and B. A. Knuth. 2011. Linking knowledge to action in collaborative conservation. Conservation Biology 25(6):1186-1194. https://doi.org/10.1111/ j.1523-1739.2011.01742.x

Leventon, J., L. Fleskens, H. Claringbould, G. Schwilch, and R. Hessel. 2016. An applied methodology for stakeholder identification in transdisciplinary research. Sustainability Science 11(5):763-775. https://doi.org/10.1007/s11625-016-0385-1

Liebenberg, F. 2015. Agricultural advisory services in South Africa. Discussion paper. Department of Agricultural Economics, Extension and Rural Development, University of Pretoria, Pretoria, South Africa.

Ma, H., Y. Lu, Y. Xing, G. He, and Y. Sun. 2009. Rural households' attitude and economic strategies toward the conversion of cropland to forest and grassland program $(\mathrm{CCFG})$ : a case study in Qira, China. Environmental Management 43(6):1039-1047. https://doi.org/10.1007/s00267-009-9290-z

Maciejewski, K., J. Baum, and G. S. Cumming. 2016. Integration of private land conservation areas in a network of statutory protected areas: implications for sustainability. Biological Conservation 200:200-206. https://doi.org/10.1016/j.biocon.2016.05.027

Maciejewski, K., and G. S. Cumming. 2015. The relevance of socioeconomic interactions for the resilience of protected area networks. Ecosphere 6(9):1-14. https://doi.org/10.1890/ES15-00022.1

Maxwell, S. L., R. A. Fuller, T. M. Brooks, and J. E. M. Watson. 2016. Biodiversity: the ravages of guns, nets and bulldozers. Nature 536:143-145. https://doi.org/10.1038/536143a

Mbaru, E. K., and M. L. Barnes. 2017. Key players in conservation diffusion: using social network analysis to identify critical injection points. Biological Conservation 210(A):222-232. https://doi.org/10.1016/j.biocon.2017.03.031

McDowell, C. R. 1988. Factors affecting the conservation of renosterveld by private landowners. Dissertation. University of Cape Town, Cape Town, South Africa. [online] URL: http://hdl. $\underline{\text { handle.net/11427/16620 }}$

McDowell, C., and E. Moll. 1992. The influence of agriculture on the decline of west coast renosterveld, south-western Cape, South Africa. Journal of Environmental Management 35 (3):173-192. https://doi.org/10.1016/S0301-4797(05)80118-5

McDowell, C., R. Sparks, J. Grindley, and E. Moll. 1989. Persuading the landholder to conserve natural ecosystems through effective communication. Journal of Environmental Management 28(3):211-225.

Metelerkamp, L. 2011. Commercial agriculture in the Swartland: investigating emerging trends towards more sustainable food production. Thesis. Stellenbosch University, Stellenbosch, South Africa. [online] URL: http://hdl.handle.net/10019.1/6716

Meyer, M. 2010. The rise of the knowledge broker. Science Communication 32(1):118-127. https://doi.org/10.1177/1075547009359797
Midgley, G. F., R. A. Chapman, B. Hewitson, P. Johnston, M. de Wit, G. Ziervogel, P. Mukheibir, L. van Niekerk, M. Tadross, B. W. van Wilgen, B. Kgope, P. D. Morant, A. Theron, R. J. Scholes, and G. G. Forsyth. 2005. A status quo, vulnerability and adaptation assessment of the physical and socio-economic effects of climate change in the Western Cape. CSIR report ENV-S-C 2005-073. University of Cape Town, Cape Town, South Africa. [online] URL: http://hdl.handle.net/11427/17144

Mills, M., J. G. Álvarez-Romero, K. Vance-Borland, P. Cohen, R. L. Pressey, A. M. Guerrero, and H. Ernstson. 2014. Linking regional planning and local action: towards using social network analysis in systematic conservation planning. Biological Conservation 169:6-13. https://doi.org/10.1016/j.biocon.2013.10.015

Mittermeier, R. A., P. R. Gil, M. Hoffmann, J. Pilgrim, T. Brooks, C. Goettsch Mittermeier, J. Lamoreux, and G. A. B. da Fonseca. 2004. Hotspots revisited: Earth's biologically richest and most endangered terrestrial ecoregions. Cemex, Mexico City, Mexico.

Mittermeier, R. A., W. R. Turner, F. W. Larsen, T. M. Brooks, and C. Gascon. 2011. Global biodiversity conservation: the critical role of hotspots. Pages 3-22 in F. E. Zachos and J. C. Habel, editors. Biodiversity hotspots: distribution and protection of conservation priority areas. Springer, Berlin, Germany. https:// doi.org/10.1007/978-3-642-20992-5 1

Mooney, H. A., J. Lubchenco, R. Dirzo, and O. E. Sala. 1995. Biodiversity and ecosystem functioning: basic principles. Pages 327-452 in V. H. Heywood and R. T. Watson, editors. Global biodiversity assessment. United Nations Environment Program and Cambridge University Press, Cambridge, UK.

Myers, N., R. A. Mittermeier, C. G. Mittermeier, G. A. B. da Fonseca, and J. Kent. 2000. Biodiversity hotspots for conservation priorities. Nature 403(6772):853-858. https://doi.org/10.1038/35002501

Napier, V. R., G. M. Branch, and J. M. Harris. 2005. Evaluating conditions for successful co-management of subsistence fisheries in KwaZulu-Natal, South Africa. Environmental Conservation 32(2):165-177. https://doi.org/10.1017/S0376892905002195

Nel, J. L., D. J. Roux, A. Driver, L. Hill, A. C. Maherry, K. Snaddon, C. R. Petersen, L. B. Smith-Adao, H. Van Deventer, and B. Reyers. 2016. Knowledge co-production and boundary work to promote implementation of conservation plans. Conservation Biology 30(1):176-188. https://doi.org/10.1111/ cobi. 12560

Newman, M. E. J. 2008. Mathematics of networks. In Palgrave Macmillan, editor. New Palgrave Dictionary of Economics. Palgrave Macmillan, London, UK. https://doi.org/10.1057/978-1-349-95121-5_2565-1

Newton, I. P., and R. S. Knight. 2005. The use of a 60-year series of aerial photographs to assess local agricultural transformations of west coast renosterveld, an endangered South African vegetation type. South African Geographical Journal 87(1):18-27. https://doi.org/10.1080/03736245.2005.9713822

Olive, A., and J. L. McCune. 2017. Wonder, ignorance, and resistance: landowners and the stewardship of endangered species. Journal of Rural Studies 49:13-22. https://doi. org/10.1016/j.jrurstud.2016.11.014 
Olsson, P., and C. Folke. 2001. Local ecological knowledge and institutional dynamics for ecosystem management: a study of Lake Racken watershed, Sweden. Ecosystems 4(2):85-104. https://doi.org/10.1007/s100210000061

Olsson, P., C. Folke, and F. Berkes. 2004. Adaptive comanagement for building resilience in social-ecological systems. Environmental Management 34:75-90. https://doi.org/10.1007/ $\underline{\text { s00267-003-0101-7 }}$

Olsson, P., C. Folke, V. Galaz, T. Hahn, and L. Schultz. 2007. Enhancing the fit through adaptive co-management: creating and maintaining bridging functions for matching scales in the Kristianstads Vattenrike Biosphere Reserve, Sweden. Ecology and Society 12(1):28. https://doi.org/10.5751/ES-01976-120128

Olsson, P., L. H. Gunderson, S. R. Carpenter, P. Ryan, L. Lebel, C. Folke, and C. S. Holling. 2006. Shooting the rapids: navigating transitions to adaptive governance of social-ecological systems. Ecology and Society 11(1):18. https://doi.org/10.5751/ES-01595-110118

Overberg Renosterveld Conservation Trust. 2018. 2018/19 annual report. Overberg Renosterveld Conservation Trust, Napier, South Africa. [online] URL: https://overbergrenosterveld.org.za/wpcontent/uploads/2019/08/ORCT-AR2019-web.pdf

Pasquini, L., R. M. Cowling, C. Twyman, and J. Wainwright. 2010. Devising appropriate policies and instruments in support of private conservation areas: lessons learned from the Klein Karoo, South Africa. Conservation Biology 24(2):470-478. https://doi.org/10.1111/j.1523-1739.2009.01344.X

Picker, M. D., and M. J. Samways. 1996. Faunal diversity and endemicity of the Cape Peninsula, South Africa - a first assessment. Biodiversity and Conservation 5:591-606. https://doi. org/10.1007/BF00137611

Poppenborg, P., and T. Koellner. 2013. Do attitudes toward ecosystem services determine agricultural land use practices? An analysis of farmers' decision-making in a South Korean watershed. Land Use Policy 31:422-429. https://doi.org/10.1016/ j.landusepol.2012.08.007

Prell, C. 2011. Social network analysis: history, theory and methodology. Sage, Thousand Oaks, California, USA.

Raimondo, D., L. von Staden, W. Foden, J. E. Victor, N. A. Helme, R. C. Turner, D. A. Kamundi, and P. A. Manyama. 2009. Red list of South African plants 2009. South African National Biodiversity Institute, Pretoria, South Africa.

Raymond, C. M., A. M. Lechner, M. Lockwood, O. Carter, R. M. B. Harris, and L. Gilfedder. 2015. Private land manager capacity to conserve threatened communities under climate change. Journal of Environmental Management 159:235-244. https://doi.org/10.1016/j.jenvman.2015.04.048

Rebelo, A. G. 1992. Red data book species in the Cape Floristic Region: threats, priorities and target species. Transactions of the Royal Society of South Africa 48(1):55-86. https://doi. org/10.1080/00359199209520256

Rebelo, A. G. 1997. Conservation. Pages 571-590 in R. M. Cowling, D. M. Richardson, and S. M. Pierce, editors. Vegetation of southern Africa. Cambridge University Press, Cambridge, UK.
Reed, M. S., M. Buenemann, J. Atlhopheng, M. Akhtar-Schuster, F. Bachmann, G. Bastin, H. Bigas, R. Chanda, A. J. Dougill, W. Essahli, A. C. Evely, L. Fleskens, N. Geeson, J. H. Glass, R. Hessel, J. Holden, A. A. R. Ioris, B. Kruger, H. P. Liniger, W. Mphinyane, D. Nainggolan, J. Perkins, C. M. Raymond, C. J. Ritsema, G. Schwilch, R. Sebego, M. Seely, L. C. Stringer, R. Thomas, S. Twomlow, and S. Verzandvoort. 2011. Cross-scale monitoring and assessment of land degradation and sustainable land management: a methodological framework for knowledge management. Land Degradation and Development 22 (2):261-271. https://doi.org/10.1002/1dr.1087

Reed, M. S., A. Graves, N. Dandy, H. Posthumus, K. Hubacek, J. Morris, C. Prell, C. H. Quinn, and L. C. Stringer. 2009. Who's in and why? A typology of stakeholder analysis methods for natural resource management. Journal of Environmental Management 90(5):1933-1949. https://doi.org/10.1016/j. jenvman.2009.01.001

Rickenbach, M. G., and A. S. Reed. 2002. Cross-boundary cooperation in a watershed context: the sentiments of private forest landowners. Environmental Management 30:584-594. https://doi.org/10.1007/s00267-002-2688-5

Rogers, E. M. 1995. Diffusion of innovations. Fourth edition. Free Press, New York, New York, USA.

Rouget, M., M. Barnett, R. M. Cowling, T. Cumming, F. Daniels, M. T. Hoffman, A. Knight, J. Manuel, J. Nel, A. Parker, D. Raimondo, and T. Rebelo. 2014. Conserving the Cape Floristic Region. In N. Allsopp, J. F. Colville, and G. A. Verboom, editors. Fynbos: ecology, evolution, and conservation of a megadiverse region. Oxford University Press, Oxford, UK. https://doi. org/10.1093/acprof:oso/9780199679584.003.0014

Rouget, M., D. M. Richardson, R. M. Cowling, J. W. Lloyd, and A. T. Lombard. 2003. Current patterns of habitat transformation and future threats to biodiversity in terrestrial ecosystems of the Cape Floristic Region, South Africa. Biological Conservation 112 (1-2):63-85. https://doi.org/10.1016/S0006-3207(02)00395-6

Roux, D. J., J. L. Nel, R.-M. Fisher, and J. Barendse. 2016. Topdown conservation targets and bottom-up management action: creating complementary feedbacks for freshwater conservation. Aquatic Conservation: Marine and Freshwater Ecosystems 26 (2):364-380. https://doi.org/10.1002/aqc. 2577

Sandström, A., and C. Lundmark. 2016. Network structure and perceived legitimacy in collaborative wildlife management. Review of Policy Research 33(4):442-462. https://doi. org/10.1111/ropr.12180

Selinske, M. J., J. Coetzee, K. Purnell, and A. T. Knight. 2015. Understanding the motivations, satisfaction, and retention of landowners in private land conservation programs. Conservation Letters 8(4):282-289. https://doi.org/10.1111/conl.12154

Spierenburg, M. 2020. Living on other people's land; impacts of farm conversions to game farming on farm dwellers' abilities to access land in the Eastern Cape, South Africa. Society and Natural Resources 33(2):280-299. https://doi.org/10.1080/08941$\underline{920.2019 .1584342}$ 
Stattersfield, A. J., M. J. Crosby, A. J. Long, D. C. Wedge, and A. P. Rayner. 1998. Endemic bird areas of the world: priorities for biodiversity conservation. BirdLife International, Cambridge, UK.

Stuckenberg, B. R. 1962. The distribution of the montane palaeogenic element in the South African invertebrate fauna. Annals of the Cape Provincial Museum 11:119-158.

Topp, E. N., and J. Loos. 2019a. Fragmented landscape, fragmented knowledge: a synthesis of renosterveld ecology and conservation. Environmental Conservation 46(2):171-179. https://doi.org/10.1017/S0376892918000498

Topp, E. N., and J. Loos. 2019b. Local and landscape level variables influence butterfly diversity in critically endangered South African renosterveld. Journal of Insect Conservation 23:225-237. https://doi.org/10.1007/s10841-018-0104-6

Turner, A. A., editor. 2012. Western Cape province state of biodiversity 2012. CapeNature Scientific Services, Stellenbosch, South Africa. [online] URL: http://www.fewlbnexus.uct.ac.za/ sites/default/files/image tool/images/

91/Cape $\% 20$ Nature $\% 20$ State $\% 20$ of $\% 20$ Biodiversity $\% 202012$.pdf

Valente, T. W., and R. L. Davis. 1999. Accelerating the diffusion of innovations using opinion leaders. Annals of the American Academy of Political and Social Science 566(1):55-67. https://doi. org/10.1177/000271629956600105

Vance-Borland, K., and J. Holley. 2011. Conservation stakeholder network mapping, analysis, and weaving. Conservation Letters 4 (4):278-288. https://doi.org/10.1111/j.1755-263X.2011.00176.x

Verbeke, W., B. Dietz, and E. Verwaal. 2011. Drivers of sales performance: a contemporary meta-analysis. Have salespeople become knowledge brokers? Journal of the Academy of Marketing Science 39(3):407-428. https://doi.org/10.1007/ s11747-010-0211-8

Vogel, C., S. C. Moser, R. E. Kasperson, and G. D. Dabelko. 2007. Linking vulnerability, adaptation, and resilience science to practice: pathways, players, and partnerships. Global Enironmental Change 17(3-4):349-364. https://doi.org/10.1016/j. gloenvcha.2007.05.002

von Hase, A., M. Rouget, and R. M. Cowling. 2010. Evaluating private land conservation in the Cape Lowlands, South Africa. Conservation Biology 24(5):1182-1189. https://doi.org/10.1111/ j.1523-1739.2010.01561.x

von Hase, A., M. Rouget, K. Maze, and N. Helme. 2003. A finescale conservation plan for Cape Lowlands renosterveld: technical report. Report CCU 2/03. Cape Conservation Unit, Botanical Society of South Africa, Claremont, South Africa. [online] URL: https://bottelaryconservancy.co.za/wp-content/ uploads/2015/10/Cape-Lowland-Renosterveld-Report.pdf

Wasserman, S., and K. Faust. 1994. Social network analysis: methods and applications. Cambridge University Press, Cambridge, UK. https://doi.org/10.1017/CBO9780511815478

West, P. C., J. M. Fly, D. J. Blahna, and E. M. Carpenter. 1988. The communication and diffusion of NIPF management strategies. Northern Journal of Applied Forestry 5(4):265-270. https://doi.org/10.1093/njaf/5.4.265
Westley, F. R., O. Tjornbo, L. Schultz, P. Olsson, C. Folke, B. Crona, and Ö. Bodin. 2013. A theory of transformative agency in linked social-ecological systems. Ecology and Society 18(3):27. https://doi.org/10.5751/ES-05072-180327

Winter, S. J., K. J. Esler, and M. Kidd. 2005. An index to measure the conservation attitudes of landowners towards Overberg Coastal Renosterveld, a critically endangered vegetation type in the Cape Floral Kingdom, South Africa. Biological Conservation 126(3):383-394. https://doi.org/10.1016/j.biocon.2005.06.015

Winter, S. J., H. Prozesky, and K. J. Esler. 2007. A case study of landholder attitudes and behaviour toward the conservation of renosterveld, a critically endangered vegetation type in Cape Floral Kingdom, South Africa. Environmental Management 40 (1):46-61. https://doi.org/10.1007/s00267-006-0086-0

Wondolleck, J. M., and S. L. Yaffee. 2000. Making collaboration work: lessons from innovation in natural resource management. Island Press, Washington, D.C., USA.

Wright, D. R. 2019. A review of alternative area-based conservation mechanisms in South Africa. Table Mountain Fund, Cape Town, South Africa. 


\section{Appendix 1.}

Question Description

1a) What are your primary sources of information about renosterveld conservation (NGO's, literature, media, GO's, farmers, university members, citizen scientists, conservation initiatives, etc.)?

Source of information

Name of Source

1b) From whom have you gotten the most accurate information regarding renosterveld conservation in the last 5 years?

\begin{tabular}{|c|c|c|c|c|c|c|}
\hline Name & $\begin{array}{l}\text { Organisation } \\
\text { / Cluster }\end{array}$ & $\begin{array}{l}\text { Type of } \\
\text { information }\end{array}$ & $\begin{array}{l}\text { Describe the } \\
\text { collaboration }\end{array}$ & $\begin{array}{l}\text { How } \\
\text { often? }\end{array}$ & $\begin{array}{l}\text { Importance } \\
\begin{array}{l}1=\text { Very } \\
\text { much } \\
2=\text { Quite a bit } \\
3=\mathrm{A} \\
\text { moderate } \\
\text { amount } \\
4=\text { Very little }\end{array}\end{array}$ & $\begin{array}{l}\text { Directionality } \\
\text { Interviewee to } \\
\text { Source } \\
\text { Source to } \\
\text { Interviewee }\end{array}$ \\
\hline
\end{tabular}

1c) From whom have you gotten advice regarding renosterveld conservation in the last 5 years?

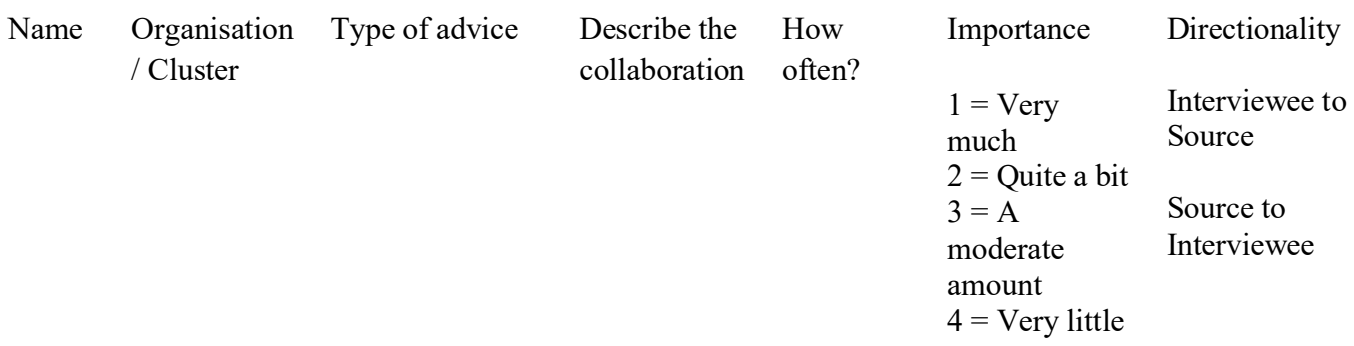

1d) From whom have you gotten new or innovative ideas regarding renosterveld conservation in the last 5 years?

\begin{tabular}{|c|c|c|c|c|c|c|}
\hline Name & $\begin{array}{l}\text { Organisation } \\
\text { / Cluster }\end{array}$ & $\begin{array}{l}\text { Describe the } \\
\text { innovative idea }\end{array}$ & $\begin{array}{l}\text { Describe the } \\
\text { collaboration }\end{array}$ & $\begin{array}{l}\text { How } \\
\text { often? }\end{array}$ & $\begin{array}{l}\text { Importance } \\
1=\text { Very } \\
\text { much } \\
2=\text { Quite a bit } \\
3=\mathrm{A} \\
\text { moderate } \\
\text { amount } \\
4=\text { Very little }\end{array}$ & $\begin{array}{l}\text { Directionality } \\
\text { Interviewee to } \\
\text { Source } \\
\text { Source to } \\
\text { Interviewee }\end{array}$ \\
\hline
\end{tabular}

1e) Who have you contacted for implementing any change regarding renosterveld conservation in the last 5 years?

\begin{tabular}{|c|c|c|c|c|c|c|}
\hline Name & $\begin{array}{l}\text { Organisation } \\
\text { / Cluster }\end{array}$ & $\begin{array}{l}\text { Describe the } \\
\text { type of change }\end{array}$ & $\begin{array}{l}\text { Describe the } \\
\text { collaboration }\end{array}$ & $\begin{array}{l}\text { How } \\
\text { often? }\end{array}$ & $\begin{array}{l}\text { Importance } \\
1=\text { Very } \\
\text { much } \\
2=\text { Quite a bit } \\
3=A \\
\text { moderate } \\
\text { amount } \\
4=\text { Very little }\end{array}$ & $\begin{array}{l}\text { Directionality } \\
\text { Interviewee to } \\
\text { Source } \\
\text { Source to } \\
\text { Interviewee }\end{array}$ \\
\hline
\end{tabular}

1f) Can you tell me the names and contact details of other people who you know to be working on renosterveld conservation? 